\title{
Pengaruh Konsistensi Diri Siswa terhadap Prestasi Belajar Matematika Siswa Kelas XI IPA SMA Negeri 1 Pangkah Kabupaten Tegal
}

\author{
Kusuma Ningtyas Pramita Resya* \\ Institut Agama Islam Bakti Negara (IBN) Tegal, Jawa Tengah, Indonesia \\ *Coresponding Author: pramitaresya@gmail.com \\ Dikirim: 15-09-2021; Direvisi: 27-09-2021; Diterima: 28-09-2021
}

\begin{abstract}
Abstrak: Penelitian ini bertujuan untuk mengetahui seberapa besar pengaruh konsistensi diri siswa terhadap prestasi belajar matematika siswa kelas XI IPA SMA Negeri 1 Pangkah Kabupaten Tegal. Metode penelitian yang digunakan untuk menganalisis dengan metode survey. Uji t untuk menguji signifikansi konstanta variabel dependen (konsistensi diri siswa). Karena $t_{\text {hitung }}>t_{\text {tabel }}$ atau 4,741 $>2,021$ maka, artinya terdapat pengaruh yang signifikan antara konsistensi diri siswa terhadap prestasi belajar matematika siswa kelas XI IPA SMA Negeri 1 Pangkah Kabupaten Tegal. Berdasarkan pengaruh antara konsistensi diri siswa (X) terhadap prestasi belajar matematika siswa kelas XI IPA SMA Negeri 1 Pangkah Kabupaten Tegal (Y) yang dihitung dengan korelasi adalah 0,61 atau $\left(\mathrm{r}_{\mathrm{xy}}=0,61\right)$. Hal ini menunjukan pengaruh yang kuat antara konsistensi diri siswa terhadap prestasi belajar matematika siswa kelas XI IPA SMA Negeri 1 Pangkah Kabupaten Tegal. Kontribusi secara bersama variabel X terhadap $\mathrm{Y}=(0,61)^{2} \times 100 \%=37,21 \%$, sedangkan $62,79 \%$ ditentukan oleh variabel lain. Dari hasil pengujian diatas dapat disimpulkan bahwa konsistensi diri siswa berpengaruh postitif terhadap prestasi belajar matematika siswa kelas XI IPA SMA Negeri 1 Pangkah Kabupaten Tegal.
\end{abstract}

Kata Kunci: Konsistensi Diri; Konsistensi Diri Siswa; Prestasi Belajar Matematika

Abstract: This study aims to determine how much influence the students' self-consistency has on the mathematics learning achievement of class XI science students at SMA Negeri 1 Pangkah, Tegal Regency. The research method used to analyze the survey method. T test to test the significance of the dependent variable constant (student self-consistency). Because tcount $>$ ttable or 4,741 >2,021, it means that there is a significant influence between students' self-consistency on mathematics learning achievement of students in class XI science at SMA Negeri 1 Pangkah, Tegal Regency. Based on the effect of student self-consistency (X) on mathematics learning achievement of class XI science students at SMA Negeri 1 Pangkah, Tegal Regency (Y) which is calculated by correlation is 0.61 or $(\mathrm{rxy}=0.61)$. This shows a strong influence between students' self-consistency on mathematics learning achievement of class XI science students at SMA Negeri 1 Pangkah, Tegal Regency. The joint contribution of the $\mathrm{X}$ variable to $\mathrm{Y}=(0.61) 2 \times 100 \%=37.21 \%$, while $62.79 \%$ is determined by other variables. From the test results above, it can be concluded that students' self-consistency has a positive effect on mathematics learning achievement for class XI science students at SMA Negeri 1 Pangkah Tegal Regency.

Keywords: Self Consistency, Student Self Consistency, Mathematics Learning Achievement

\section{PENDAHULUAN}

Pendidikan pada dasarnya merupakan upaya paling utama untuk mencerdaskan kehidupan bangsa. Hanya dengan pendidikan yang bermutu kita dapat membangun keunggulan dalam menghadapi persaingan global yang semakin cepat. Pendidikan merupakan salah satu faktor yang sangat penting artinya dalam kehidupan manusia

@ 2021 JagoMipa (https://jurnal.bimaberilmu.com/index.php/jagomipa) 
dan tidak dapat dipisahkan darinya dimanapun berada. Karena sifatnya yang mutlak itulah maka dalam setiap aspek kehidupan manusian baik secara pribadi, kelompok, keluarga, maupun dalam berbangsa dan bernegara, pendidikan wajib dilaksanakan. Menurut undang-undang No.20 tahun 2003 tentang sistem pendidikan nasional pasal 1 ayat (1) menyebutkan bahwa: Pendidikan adalah usaha sadar dan terencana untuk mewujudkan suasana belajar dan proses pembelajaran agar peserta didik secara aktif mengembangkan potensi dirinya untuk memiliki kekuatan spiritual keagamaan, pengendalian diri, kepribadian, kecerdasan, akhlak mulia, dan keterampilan yang diperlukan dirinya, masyarakat, bangsa dan negara.

Somantrie (2009:2) mengemukakan bahwa "peningkatan mutu pendidikan di Indonesia pada hakikatnya merupakan upaya untuk meningkatkan mutu dan daya saing lulusan yang diukur dari kecakapan akademik dan non-akademik yang mengacu pada standar nasional pendidikan". Mutu pendidikan salah satunya dipengaruhi oleh proses belajar mengajar yang berkualitas sehingga akan menghasilkan peserta didik yang berkualitas pula. Untuk mencapai kegiatan belajar mengajar yang efektif dan efisien, guru harus mampu menciptakan suasana belajar yang nyaman dan dapat membentuk kepribadian konsisten pada diri siswa. Wahidmurni,dkk (2010:1) mengatakan bahwa "kompetensi adalah sekumpulan kemampuan dasar yang harus dimiliki guru agar dapat melaksanakan tugasnya dengan baik dan kompetensi ini dijabarkan kedalam empat kemampuan yakni kompetensi paedagogik", kompetensi kepribadian, kompetensi sosial, dan kompetensi professional. Seorang guru harus memiliki kompetensi-kompetensi tersebut karena guru sebagai salah satu komponen pelaksana utama dan ujung tombak pendidikan. Robbins,dkk (2010:41) mengatakan bahwa "konsistensi berarti setiap individu berusaha untuk menyelaraskan sikap dan perilaku agar terlihat rasional dan konsisten”. Sikap yang teguh pendiriannya dalam bertindak sehingga dapat menyelaraskan antara ucapan dan perilaku.

Dengan sebuah keyakinan penuh akan membantu diri kita untuk selalu berbuat konsisten terhadap sesuatu yang kita anggap baik, karena apa yang kita lakukan sebenarnya diawali oleh pikiran-pikiran kita. Konsistensi memang tidak akan muncul tiba-tiba, perlu waktu dan pembiasaan sehingga seseorang dapat berlaku konsisten. Semangat inilah yang sebenarnya harus dibangun disekolah dan dimulai oleh guru. Konsistensi yang berarti tanpa perbedaan atau kontradiksi ini hanya bisa diajarkan dari sebuah keteladanan. Setiap tindakan yang dilakukan sesorang akan berdampak baik bagi dirinya maupun orang lain terlepas apa yang dilakukan itu baik atau buruk. Dalam hal ini sungguh perilaku guru yang konsisten atas apa yang disampaikannya, akan membentuk pribadi siswa yang dididiknya menjadi konsisten pula. Tentunya perilaku untuk memperlakukan tugas siswa dengan sebagaimana mestinya. Setiap siswa harus membiasakan diri untuk selalu konsisten dalam belajar dan mengerjakan tugas-tugas yang telah diberikan oleh guru dengan tepat waktu maka akan meningkatkan prestasi belajar siswa khususnya dalam bidang matematika.

Dalam belajar matematika salah satu fator untuk meningkatkan prestasi belajar matematika yaitu dibutuhkan konsistensi diri dalam diri siswa SMA Negeri 1 Pangkah Kabupaten Tegal. Konsistensi yang muncul dari dalam diri merupakan bentuk dari aspek keteguhan hati. Jika siswa memiliki keteguhan hati dalam belajar maka siswa tersebut tidak akan berhenti belajar ditengah jalan sebelum tujuan belajarnya mencapai prestasi yang diharapkan. Dari hasil wawancara dengan guru matematika kelas XI IPA SMA Negeri 1 Pangkah Kabupaten Tegal, juga diperoleh keterangan bahwa pada

@ 2021 JagoMipa (https://jurnal.bimaberilmu.com/index.php/jagomipa) 
dasarnya sebagian besar siswa sudah mempunyai minat yang cukup besar untuk belajar matematika. Namun, kurangnya siswa dalam membiasakan dirinya untuk konsisten dalam belajar, yang berarti konsistensi diri siswa kelas XI IPA SMA Negeri 1 Pangkah Kabupaten Tegal masih tergolong rendah. Untuk menumbuhkan konsistensi diri siswa, perlu dirancang suatu pembelajaran yang membiasakan siswa untuk konsisten dalam belajar sehingga siswa lebih mampu meningkatkan prestasi belajar matematika. Guru tersebut juga mengatakan bahwa nilai matematika pada siswa kelas XI IPA SMA IPA Negeri 1 Pangkah Kabupaten Tegal perstasinya masih tergolong rendah karena dilihat dari prosentase siswa yang masih dibawah KKM kurang lebih sekitar 35\%. Dimana standar nilai KKM disekolah tersebut adalah 75,0.

Rendahnya prestasi belajar matematika yang sering menjadi masalah yang dihadapi siswa disekolah, jelas dapat dipengaruhi oleh kurangnya membiasakan diri untuk selalu konsisten dalam belajar. Karena dalam belajar matematika konsistensi diri merupakan salah satu yang sangatlah penting. Misalnya untuk dapat mengerjakan soal ulangan matematika dengan baik maka siswa kelas XI IPA SMA Negeri 1 Pangkah Kabupaten Tegal harus sering berlatih mengerjakan soal-soal matematika secara konsisten, dengan siswa konsisten berlatih belajar maka siswa tersebut dapat mengerjakan soal ulangan matematika dengan baik dan menghasilkan nilai yang memuaskan. Karena belajar matematika tidak bisa hanya dihafal dan bukan hanya dengan membaca bukunya saja tetapi harus sering terus berlatih mengerjakan soal-soal matematika tersebut, sehingga dapat meningkatkan prestasi belajar matematika siswa. Dengan membiasakan diri siswa SMA Negeri 1 Pangkah Kabupaten Tegal untuk selalu konsisten dalam belajar, dengan sendirinya akan terbentuk kedisplinan dan keteladanan dalam belajar pula.

Dari uraian diatas, perlu diteliti lebih lanjut secara seksama dengan menitikberatkan konsistensi diri siswa SMA Negeri 1 Pangkah Kabupaten Tegal. Berdasarkan refrensi yang ada konsistensi diri siswa dapat meningkatkan prestasi belajar matematika. Untuk mengetahui dan mendapatkan informasi yang lebih jelas, maka perlu dilakukan penelitian dan untuk itu skripsi ini diberi judul "Pengaruh Konsistensi Diri Siswa Terhadap Prestasi Belajar Matematika Siswa Kelas XI IPA SMA Negeri 1 Pangkah Kabupaten Tegal”.

\section{KAJIAN TEORI}

\section{Konsistensi diri siswa}

Cahya (2008: 71) berpendapat bahwa "Konsistensi merupakan komponen aset diri”. Konsistensi menunjukan apa yang anda pilih untuk anda lakukan berulang-ulang sebagai kebiasaan. Konsistensi berarti jalan terus hingga mencapai tujuan dan harapan, walaupun jalan anda menemui tantangan, kesulitan dan ketidak-nyamanan. Setiap orang menginginkan konsistensi, setiap orang menghargai konsistensi. Itu sebabnya konsistensi yang ada pada dalam diri menjadi syarat mutlak dalam meraih kesuksesan. Karena untuk mencapai kesuksesan membutuhkan proses dan waktu yang tidak singkat.

Harianto (2008: 90) berpendapat bahwa "konsistensi berasal dari kata konsisten, berarti tetap, selaras dan sesuai". Konsistensi merupakan keadaan yang mencerminkan kesesuaian dan keselarasan antara pikiran, perkataan dan perbuatan. Konsistensi tidak bisa tumbuh tanpa adanya kehendak atau kesungguhan dari dalam hati seseorang itu sendiri. Dengan sebuah keyakinan penuh akan membantu diri kita untuk selalu berbuat 
konsisten terhadap sesuatu yang kita anggap baik, karena apa yang kita lakukan sebenarnya diawali oleh pikiran-pikiran kita.

Besten (2010: 120) menyatakan bahwa "ketetapan hati (konsistensi diri) adalah keteguhan akan tujuan, kehendak dan niat". Konsistensi yang ada dalam diri diperlukan untuk menyelesaikan suatu masalah, melengkapi suatu tugas, dan untuk berkembang secara terus-menerus. Siswa yang membiasakan diri untuk selalu konsisten dalam hal apapun, maka secara tidak disadari didalam dirinya akan tumbuh sebuah keteladanan.

Leonard (2015:100) konsistensi diri adalah sikap seseorang yang tetap, selaras, sesuai, dan teguh memegang prinsip yang diyakini untuk mencapai kehendak, minat, serta tujuan yang diinginkan. Konsistensi memang tidak akan muncul tiba-tiba, perlu waktu dan pembiasaan sehingga seseorang dapat berlaku konsisten. Semangat inilah yang sebenarnya harus dibangun disekolah dan dimulai oleh guru. Konsistensi yang berarti tanpa perbedaan atau kontradiksi ini hanya bisa diajarkan dari sebuah keteladanan. Setiap tindakan yang dilakukan seseorang akan berdampak baik bagi dirinya maupun orang lain terlepas apa yang dilakukan itu baik atau buruk.

Nashori (2011:175) "konsistensi diri adalah kemampuan untuk menjaga irama hati dan perilaku kita sehingga kita mampu secara terus menerus memberi perhatian terhadap apa yang kita yakini sebagai sesuatu yang berharga. Yakin dengan apa yang telah diri kita perbuat, yakin dengan apa yang akan diperbuat serta yakin dengan hasil yang telah diperbuatnya akan menghasilkan sesuatu sesuai dengan tujuan yang ingin dicapai. Dengan adanya konsistensi diri pada perilaku yang kita, sehingga apa yang kita lakukan dalam suatu bidang tertentu tidak akan pernah mengubah apa yang telah kita yakini.

Dari uraian diatas dapat disimpulkan bahwa konsistensi diri siswa merupakan sikap yang teguh pendiriannya dalam bertidak yang harus ada dalam diri seorang siswa dengan membiasakan dirinya selalu berperilaku konsisten sehingga selaras antara ucapan dan perbuatan serta tumbuh motivasi dalam dirinya. Dengan siswa selalu berperilaku konsisten maka dengan begitu siswa akan bisa mengarahkan dirinya sendiri antara ucapan dengan tindakan selalu sama walaupun dalam waktu yang berbeda, sehingga secara tidak langsung didalam diri siswa tersebut akan tumbuh sebuah keteladanan dan kedisiplinan.

\section{Prestasi Belajar Matematika}

Perubahan tingkah laku sebagai prestasi belajar diatas bagi individu merupakan kemampuan baru dalam bidang kognitif, afektif dan psikomotorik, yaitu sebagai kemampuan yang betul-betul baru di peroleh atau sebagai hasil perbaikan atau peningkatan dari kemampuan sebelumnya. Kadir (2011:204) mengatakan bahwa "belajar adalah suatu tahapan tingkah yang relative menetap sebagai hasil dari pengalaman, latihan dan interaksi dengan lingkungan yang melibatkan proses kognitif". Pengalaman adalah guru yang paling berharga dan dengan mengalami langsung proses belajar, kepekaan panca indra khususnya ingatan siswa akan bertahan lama dalam menyimpan memori akan usaha belajar yang dilakukan.

Achdiyat (2016:53) belajar merupakan unsur yang sangat fundamental dalam penyelenggaraan pendidikan yang tercipta dari suatu kemampuan berpikir alamiah yang menyangkut hubungan antara stimulus dan respon yang berlangsung terusmenerus dan merupakan reaksi yang dipengaruhi oleh factor-faktor proses belajar terhadap lingkungan sehingga terbentuk perubahan yang berasal dari pengalaman. 
Perubahan ini dengan sendirinya dialami tiap-tiap individu atau manusia, terutama hanya sekali sejak manusia dilahirkan. Sejak saat itu, terjadi perubahan-perubahan dalam arti perkembangan melalui fase-fasenya. Dan karena itu pula, sejak saat itu berlangsung proses-proses belajar. Perubahan sebagai hasil dari proses belajar dapat ditunjukan dalam berbagai bentuk seperti perubahan pengetahuan, pemahaman, sikap dan tingkah laku, keterampilan, kecakapan dan kemampuan, serta perubahanperubahan aspek lain yang ada pada individu yang belajar. Adanya usaha atau aktifitas yang sengaja dilakukan oleh orang yang belajar dengan pengalaman (memperhatikan, mengamati, memikirkan, merasakan, menghayati dan sebagainya) atau dengan latihan (melatih, meniru).

Matematika adalah salah satu mata pelajaran yang menduduki peranan penting dalam pendidikan. Hal ini disebabkan karena matematika digunakan secara luas dalam segala bidang kehidupan manusia. Oleh karena itu pelajaran matematika dalam pelaksanaan pendidikan diberikan kepada jenjang pendidikan mulai dari Sekolah Dasar (SD) sampai dengan Perguruan Tinggi (PT). Tatan Z.M dan Teti (2011:73) mengatakan bahwa "matematika merupakan ilmu pasti yang menuntut pemahaman dan ketekunan berlatih". Ketekunan berlatih dan membiasakan diri mengerjakan soalsoal matematika, maka siswa akan cepat paham dengan sendirinya tentang pelajaran yang akan siswa kuasai. Ciri utama matematika adalah penalaran deduktif yaitu kebenaran suatu konsep atau pernyataan diperoleh sehingga akibat logis dari kebenaran sebelumnya sehingga kaitan antara konsep atau pernyataan dalam matematika bersifat konsisten.

Nugraha (2018: 63) prestasi belajar matematika adalah perubahan-perubahan tingkah laku siswa sebagai indikator tingkat ketercapaian tujuan belajar matematikadalam penguasaan struktur kognitif berupa fakta-fakta, dan konsep-konsep setelah mendapatkan pengalaman belajar di bidang matematika. Prestasi belajar matematika juga dapat berpengaruh terhadap penguasaan materi pelajaran lain, sikap dan keterampilan. Leonard (2015:101) prestasi belajar matematika yaitu skor tentang kemampuan atau tingkat penguasaan materi pelajaran berupa konsep matematika yang diperoleh siswa selama proses belajar mengajar dan mampu memecahkan masalah matematika sesuai dengan tujuan pembelajaran matematika. Peserta didik yang lebih menekuni pelajaran matematika akan berpengaruh terhadap sikap dan tingkah laku sehari-hari seperti dalam pengambilan keputusan peserta didik akan mengambil keputusan secara simple dan tidak bertele-tele tetapi tepat sasaran seperti kalau peserta didik mengerjakan soal matematika, mengerjakan sesuai ketentuan yang ada, tanpa ada tambahan alasan dengan kata lain prestasi belajar matematika akan berpengaruh baik terhadap penilaian psikomotorik, efektif, dan kognitif didalam pelajaran dan dalam kehidupan sehari-hari.

Dari uraian diatas dapat disimpulkan bahwa prestasi belajar matematika adalah kemampuan dalam menguasai pelajaran yang telah dicapai oleh siswa setelah terjadinya proses belajar matematika yang dapat dilihat dan diukur dengan menggunakan alat evaluasi berupa tes. Prestasi belajar matematika merupakan pengetahuan yang dimiliki oleh siswa dari belajar matematika yang meliputi pengertian, pemahaman, penguasaan akan konsep perhitungan serta pemecahan problema matematika. Dalam belajar matematika tidak hanya dengan membaca saja melainkan harus sering berlatih mengerjakan soal-soal matematika sehingga mendapatkan hasil yang sesuai dengan harapan. 


\section{METODE PENELITIAN}

Jenis penelitian yang penulis lakukan adalah penelitian kuantitatif. Metode yang digunakan dalam penelitian ini adalah metode survey asosiatif (survey kolerasional), yaitu metode yang bertujuan untuk memeriksa, meneliti, melihat dari dekat untuk mengetahui atau menemukan pengaruh terhadap masalah Data-data dalam penelitian ini diperoleh berdasarkan pemberian soal tes evaluasi prestasi belajar matematika siswa dan pemberian angket konsistensi diri siswa.

\section{Desain Penelitian}

Variabel-variabel dalam penelitian ini adalah konsistensi diri siswa kelas XI IPA SMA Negeri 1 Pangkah sebagai variabel bebas dan prestasi belajar matematika sebagai variabel terikat. Sedangkan desain penelitian sebagai berikut:

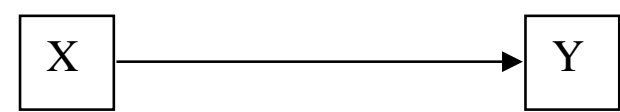

Gambar.1 Desain Penelitian

Ket : $\quad X=$ Konsistensi Diri Siswa

$\mathrm{Y}=$ Prestasi Belajar Matematika Siswa Kelas XI IPA SMA Negeri 1 Pangkah

\section{Teknik Sampling}

Teknik pengambilan sampel dalam penelitian ini dilakukan dengan cara menggunakan teknik sampel cluster random sampling (area sampling), yaitu pengambilan sampel secara acak dari populasi yang berkelompok. Pada penelitian ini, tahap pertama menentukan dua kelas secara random (acak) dari empat kelas XI IPA yaitu kelas XI IPA 3 dan XI IPA 4 yang terdapat di SMA Negeri 1 Pangkah Kabupaten Tegal. Tahap selanjutnya, diambil secara acak. Untuk sekedar ancer-ancer, maka apabila subjeknya kurang dari seratus lebih baik diambil semua sehingga penelitiannya merupakan penelitian populasi. Tetapi jika jumlah subjeknya besar, dapat diambil antara $10 \%$ sampai $15 \%$ atau 20\% sampai $25 \%$ atau lebih (Arikunto,2006:134). Maka dalam pelelitian ini diambil sampel sebanyak 40 siswa sebagai sampel.

\section{Teknik Pengumpulan Data}

a. Teknik mendapatkan data mengenai konsistensi diri siswa (X)

Pengumpulan untuk mendapatkan data tentang konsistensi diri siswa dilakukan dengan penyebaran angket kepada siswa kelas XI IPA SMA Negeri 1 Pangkah sebagai sampel penelitian.

b. Teknik mendapatkan data prestasi belajar matematika (Y)

Pengumpulan data tentang prestasi belajar matematika diperoleh dari tes evaluasi yang diberikan kepada siswa kelas XI IPA SMA Negeri 1 Pangkah sampel penelitian. 


\section{Instrumen Penelitian}

1. Instrumen Prestasi Belajar Matematika

Tabel 1. Kisi-kisi Prestasi Belajar Matematika

\begin{tabular}{|c|c|c|c|}
\hline Materi Ajar & Kompetensi Dasar & Indikator & $\begin{array}{l}\text { No. } \\
\text { Soal }\end{array}$ \\
\hline Limit Fungsi & $\begin{array}{l}\text { Menjelaskan secara } \\
\text { intuitif arti limit } \\
\text { fungsi di suatu titik } \\
\text { dan di takhingga } \\
\text { dan menggunakan } \\
\text { sifat limit fungsi } \\
\text { untuk menghitung } \\
\text { bentuk tak tentu } \\
\text { fungsi aljabar dan } \\
\text { trigonometri. }\end{array}$ & $\begin{array}{l}\text { - Menghitung limit } \\
\text { fungsi aljabar di suatu } \\
\text { titik dan tak hingga. } \\
\text { - Menggunakan sifat } \\
\text { limit fungsi untuk } \\
\text { menghitung bentuk tak } \\
\text { tentu fungsi aljabar. } \\
\text { - Menghitung limit } \\
\text { fungsi trigonometri di } \\
\text { suatu titik. } \\
\text { Menentukan limit } \\
\text { fungsi bentuk tak tentu } \\
\text { serta menggunakan } \\
\text { teorema-teorema limit } \\
\text { dalam. }\end{array}$ & $\begin{array}{l}19 \\
13,14, \\
15,16, \\
17,18, \\
20\end{array}$ \\
\hline
\end{tabular}

Dari hasil perhitungan dapat disimpulkan bahwa derajat kesukaran soal secara keseluruhan adalah mudah dan sedang dengan rata-rata 0,63.

Nilai $r_{p b i s}\left(r_{\text {hitung }}\right)$ yang diperoleh dari perhitungan selanjutnya dikonsultasikan dengan $r_{\text {tabel }}$ product moment. Pengujian validitas bitur soal ini dilakukan pada 32 responden, maka nilai $r_{\text {tabel }}$ pada taraf signifikansi $\alpha=0,05 \mathrm{df}$ $=\mathrm{n}$ (dimana $\mathrm{n}=$ jumlah responden) adalah 0,349. Berdasarkan hasil perhitungan validitas instrument tes prestasi belajar matematika ditemukan nomor butir soal 8 , 10, 14, 20 yang tidak memenuhi atau tidak valid. Butir soal yang tidak valid akan dihilangkan (dibuang), sedangkan butir yang dinyatakan valid digunakan untuk penelitian.

Pengujian reliabilitas perangkat soal ini pada 16 soal yang valid, maka nilai $\mathrm{r}_{\text {tabel }}$ pada taraf signifikansi $\alpha=0,05 \mathrm{df}=\mathrm{k}$ (dimana $\mathrm{k}=$ banyaknya soal yang valid) adalah 0,497 . Untuk butir soal prestasi belajar matematika ini memiliki reliabilitas $=0,8245$. Karena $r_{\text {hitung }}>r_{\text {tabel }}$ maka dapat dikatakan bahwa butir soal prestasi belajar matematika dikatakan reliabel.

\section{Instrumen Konsistensi Diri Siswa}

Tabel.2 Kisi-kisi konsistensi diri siswa

\begin{tabular}{|c|l|l|l|c|c|}
\hline \multirow{2}{*}{ Variabel } & \multicolumn{1}{|c|}{ Indikator } & \multicolumn{2}{|c|}{ Sifat } & \multicolumn{2}{c|}{ Jumlah } \\
\cline { 3 - 6 } & & \multicolumn{1}{|c|}{$\mathrm{P}$} & $\mathrm{N}$ & $\mathrm{P}$ & $\mathrm{N}$ \\
\hline \multirow{4}{*}{$\begin{array}{c}\text { Konsistensi } \\
\text { Diri }\end{array}$} & Disiplin & $1,2,3,23$ & $4,5,6$, & 4 & 3 \\
\cline { 2 - 7 } & $\begin{array}{l}\text { Menyelaraskan } \\
\text { Sikap dan perilaku }\end{array}$ & $\begin{array}{l}7,8,9,10, \\
21,24\end{array}$ & $\begin{array}{l}11,12,13,14, \\
25\end{array}$ & 6 & 5 \\
\cline { 2 - 7 } & Keteladanan & $15,16,17$ & $18,19,20,22$ & 3 & 4 \\
\hline
\end{tabular}

Adapun syarat bahwa butir soal dikatakan valid adalah benar jika $t_{\text {hitung }}>$ $t_{\text {tabel }}$, namun jika $t_{\text {hitung }}<t_{\text {tabel }}$ maka butir soal dinyatakan drop atau tidak valid. Kegiatan instrument penelitian ini diuji cobakan kepada 32 siswa kelas XI IPA 
SMA 1 Pangkah untuk angket. Dengan demikian $t_{\text {tabel }}$ yang digunakan sebagai kriteria tingkat penerimaan dengan kepercayaan $5 \%$ adalah 0,349 .

Berdasarkan perhitungan uji coba validitas angket konsistensi diri siswa, ditemukan tiga butir soal yang tidak memenuhi persyaratan karena $r_{\text {hitung }}<r_{\text {tabel. }}$. Butir soal tersebut adalah butir soal nomor 2, 10, dan 16. Butir soal yang tidak valid akan dihilangkan (dibuang), sedangkan butir yang dinyatakan valid digunakan untuk penelitian.

Pengujian reliabilitas perangkat soal ini pada 22 soal yang valid, maka nilai $\mathrm{r}_{\text {tabel }}$ pada taraf signifikansi $\alpha=0,05 \mathrm{df}=\mathrm{k}$ (dimana $\mathrm{k}=$ banyaknya soal yang valid) adalah 0,423. Berdasarkan hasil uji coba angket dengan rumus Alpha Cronbach diperoleh hasil sebesar $r_{\text {hitung }}=0,821$ karena jika $r_{\text {hitung }}>r_{\text {tabel }}$ maka instrument tersebut dikatakan reliabel.

\section{HASIL DAN PEMBAHASAN}

\section{Hasil Penelitian}

Analisis Deskripsi Data

Tabel.3 Kesimpulan Analisis Deskripsi Data

\begin{tabular}{|l|l|l|l|l|l|l|}
\hline Variabel & $\begin{array}{l}\text { Nilai } \\
\text { rendah }\end{array}$ & $\begin{array}{l}\text { Nilai } \\
\text { tinggi }\end{array}$ & Mean & Median & Modus & $\begin{array}{l}\text { Simpangan } \\
\text { Baku }\end{array}$ \\
\hline $\mathrm{X}$ & 60 & 89 & 75,5 & 75,6 & 75,35 & 7,94 \\
\hline $\mathrm{Y}$ & 63 & 92 & 78,5 & 78,35 & 75,35 & 8,26 \\
\hline
\end{tabular}

\section{Pengujian Persyaratan Analisis}

1. Uji Normalitas

Dengan membandingkan $X^{2}$ hitung dengan $X^{2}$ tabel untuk $\alpha=0,05$ dan derajat kebebasan $(\mathrm{dk})=\mathrm{k}-1=6-1=5$, kemudian dicari pada tabel Chi-Kuadrat didapat $\mathrm{X}^{2}$ tabel $=11,070$ dengan kriteria pengujian sebagai berikut:

Jika, $\left(\mathrm{X}^{2}\right.$ hitung $) \geq\left(\mathrm{X}^{2}\right.$ tabel $)$ maka ditribusi data tidak normal.

Jika, $\left(\mathrm{X}^{2}\right.$ hitung $) \leq\left(\mathrm{X}_{\text {tabel }}{ }\right)$ maka ditribusi data normal.

Ternyata $\left(\mathrm{X}_{\text {hitung }}^{2}\right) \leq\left(\mathrm{X}_{\text {tabel }}^{2}\right)$ atau $6,5728<11,070$ maka data prestasi belajar matematika berdistribusi normal.

2. Uji Linearitas Regresi

Ternyata $F_{\text {hitung }}<\mathrm{F}_{\text {tabel }}$ atau $1,73<2,13$ maka Ho diterima artinya data berpola linear.

\section{Pengujian hipotesis Penelitian}

Nilai $r_{x y}=0,61$ karena nilai $r_{x y}$ terdapat pada interval koefisien $0,61-0,80$. Korelasi Product Moment (Pearson) konsistensi diri siswa terhadap prestasi belajar matematika siswa kelas XI IPA SMA Negeri 1 Pangkah Kabupaten Tegal kedalam tingkat hubungan yang kuat.

Kaidah Keputusan:

Jika $t_{\text {hitung }}>t_{\text {tabel }}$, maka Ho ditolak, artinya signifikan.

Jika $t_{\text {hitung }}<\mathrm{t}_{\text {tabel }}$, maka Ho diterima, artinya tidak signifikan.

Berdasarkan perhitungan diatas, $\alpha=0,05$ dan $n=40$, uji pihak $d k=n-2=40-2=38$ sehingga diperoleh $t_{\text {tabel }}=2,021$. Ternyata $t_{\text {hitung }}>t_{\text {tabel }}$ atau 4,741 $>2,021$ maka Ho ditolak, artinya terdapat pengaruh yang signifikan antara konsistensi diri siswa 
terhadap prestasi belajar matematika siswa kelas XI IPA SMA Negeri 1 Pangkah Kabupaten Tegal.

Koefisien determinasi dimaksudkan untuk mengetahui seberapa besar prosentase faktor variabel penyebab mempengaruhi faktor akibat. Rumus koefisien determinasi adalah:

$\mathrm{KD}=\mathrm{r}^{2} \times 100 \%$

$=(0,61)^{2} \times 100 \%$

$=0,3721 \times 100 \%$

$=37,21 \%$

Artinya variabel kosistensi diri siswa memberikan pengaruh terhadap prestasi belajar matematika siswa kelas XI IPA SMA Negeri 1 Pangkah Kabupaten Tegal sebesar $37,21 \%$ dan sisanya $62,79 \%$ ditentukan oleh variabel lain.

Persamaan regresi sederhana yang didapat adalah:

$\overline{\mathrm{Y}}=\mathrm{a}+\mathrm{bX}$

$\bar{Y}=21,24+0,76 X$

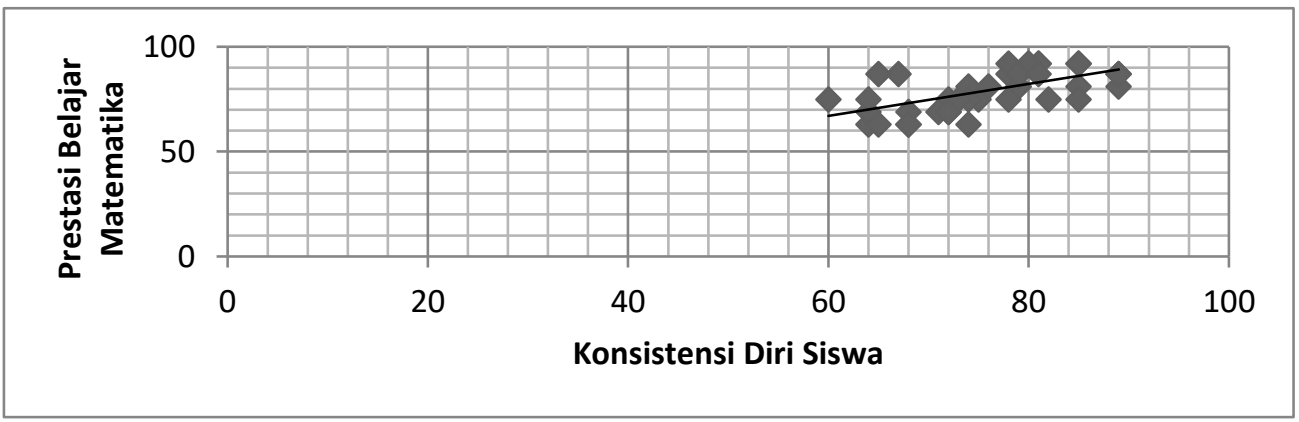

Gambar.2 Diagram Pencar Pengaruh Konsistensi Diri Siswa Terhadap Prestasi Belajar Matematika

\section{Pembahasan}

Setelah dilakukan penelitian mengenai pengaruh antara variabel konsistensi diri siswa (X) terhadap prestasi belajar matematika siswa kelas XI IPA SMA Negeri 1 Pangkah Kabupaten Tegal (Y), dengan responden 40 siswa. Maka diperoleh hasil perhitungan sebagai berikut:

Uji normalitas dilakukan dengan uji chi-kuadrat. Hasil pengujian normalitas untuk konsistensi diri siswa $X_{\text {hitung }}^{2}=4,524$ dengan $\mathrm{n}=40$ dan $\alpha=0,05$. Dari daftar nilai uji chi-kuadrat didapat $X_{\text {tabel }}^{2}=11,070$ yang lebih besar dari $X_{\text {hitung }}^{2}=4,524$. Sedangkan hasil pengujian normalitas untuk prestasi belajar matematika kelas XI IPA SMA Negeri 1 Pangkah Kabupaten Tegal didapat $X_{\text {hitung }}^{2}=6,5728$ dengan $\mathrm{n}=40$ dan $\alpha=0,05$. Dari daftar nilai uji chi-kuadrat didapat $X_{\text {tabel }}^{2}=11,070$ yang lebih besar dari $x_{\text {hitung }}^{2}=6,5728$. Dari kedua pengujian normalitas tersebut didapat $x_{\text {tabel }}^{2}>x_{\text {hitung }}^{2}$, sehingga kedua populasi tersebut berdistribusi normal. Dengan demikian pengujian persyaratan analisis yaitu data berdistribusi normal terpenuhi.

Uji linearitas, pengujian diperoleh $F_{\text {hitung }}=1,73$ pada $\alpha=0,05$ dengan $\mathrm{dk}$ pembilang $=16$ dan $\mathrm{dk}$ penyebut $=22$, maka didapat $\mathrm{F}_{\text {tabel }}=2,13$. Dari pengujian linearitas tersebut didapat $\mathrm{F}_{\text {hitung }}<\mathrm{F}_{\text {tabel }}$ atau $1,73<2,13$, sehingga dapat disimpulkan 
data berpola linear. Dengan demikian pengujian normalitas yaitu data beregresi linear terpenuhi.

Uji keberartian koefisien korelasi antara konsistensi diri siswa terhadap prestasi belajar matematika kelas siswa XI IPA SMA Negeri 1 Pangkah Kabupaten Tegal didapat $t_{\text {hitung }}=4,741$ pada $\alpha=0,05$ dan $\mathrm{n}=40$, dengan $\mathrm{dk}=\mathrm{n}-2=40-2=38$ sehingga diperoleh $\mathrm{t}_{\text {tabel }}=2,021$. Ternyata $t_{\text {hitung }}>\mathrm{t}_{\text {tabel }}$ atau 4,741 $>2,021$ maka Ho ditolak, artinya terdapat pengaruh yang signifikan antara konsistensi diri siswa terhadap prestasi belajar matematika siswa kelas XI IPA SMA Negeri 1 Pangkah Kabupaten Tegal.

Berdasarkan pengaruh antara variabel konsistensi diri siswa (X) terhadap prestasi belajar matematika siswa kelas XI IPA SMA Negeri 1 Pangkah Kabupaten Tegal (Y) yang dihitung dengan korelasi 0,61 atau $r_{x y}=0,61$. Hal ini menunjukan pengaruh yang kuat antara konsistensi diri siswa terhadap prestasi belajar matematika siswa kelas XI IPA SMA Negeri 1 Pangkah Kabupaten Tegal. Kontribusi secara bersama $X$ terhadap $Y=r^{2} \times 100 \%=(0,61)^{2} \times 100 \%=37,21 \%$, sedangkan sisanya $62,79 \%$ ditentukan oleh variabel lain yang tidak dibahas dalam penelitian ini.

Dari perhitungan regresi menggambarkan bahwa persamaan regresi sebagai berikut: $\bar{Y}=21,24+0,76 \mathrm{X}$, dimana $: \mathrm{X}=$ konsistensi diri siswa, $\mathrm{Y}=$ prestasi belajar matematika siswa kelas XI IPA SMA Negeri 1 Pangkah Kabupaten Tegal. Konstanta sebesar 21,24 menyatakan bahwa jika tidak ada kenaikan nilai dari variabel konsistensi diri siswa (X) terhadap prestasi belajar matematika siswa kelas XI IPA SMA Negeri 1 Pangkah Kabupaten Tegal (Y) adalah 21,24. Koefisien regresi sebesar 0,76 menyatakan bahwa setiap penambahan satu skor atau nilai konsistensi diri siswa akan memberikan peningkatan skor sebesar 0,76.

Dari hasil pengujian diatas mengenai pengaruh antara variabel konsistensi diri siswa (X) terhadap prestasi belajar matematika siswa kelas XI IPA SMA Negeri 1 Pangkah Kabupaten Tegal (Y), dapat disimpulkan bahwa konsistensi diri siswa berpengaruh postitif terhadap prestasi belajar matematika siswa kelas XI IPA SMA Negeri 1 Pangkah Kabupaten Tegal. Pengaruh yang kuat, artinya semakin tinggi konsistensi diri siswa maka semakin tinggi pula prestasi belajar matematika dan sebaliknya semakin rendah konsistensi diri siswa maka semakin rendah pula prestasi belajar matematika siswa kelas XI IPA SMA Negeri 1 Pangkah Kabupaten Tegal.

\section{KESIMPULAN}

Hasil penelitian ini menginformasikan bahwa konsistensi diri siswa mempunyai kaitan positif terhadap prestasi belajar matematika siswa kelas XI IPA SMA Negeri 1 Pangkah Kabupaten Tegal. Dengan demikian konsistensi diri siswa akan membentuk keberhasilan siswa yang menunjukan suatu kegiatan yang berdampak positif untuk meningkatkan prestasi belajar matematika siswa kelas XI IPA SMA Negeri 1 Pangkah Kabupaten Tegal.

Berdasarkan pengaruh antara variabel konsistensi diri siswa (X) terhadap prestasi belajar matematika siswa kelas XI IPA SMA Negeri 1 Pangkah Kabupaten Tegal (Y) yang dihitung dengan korelasi 0,61 atau rxy $=0,61$. Hal ini menunjukan pengaruh yang kuat antara konsistensi diri siswa terhadap prestasi belajar matematika siswa kelas XI IPA SMA Negeri 1 Pangkah Kabupaten Tegal. Kontribusi secara bersama $X$ terhadap $Y=r 2 \times 100 \%=(0,61) 2 \times 100 \%=37,21 \%$, sedangkan sisanya $62,79 \%$ ditentukan oleh variabel lain yang tidak dibahas dalam penelitian ini. 


\section{DAFTAR PUSTAKA}

Achdiyat, Maman. (2016). Prestasi Belajar Matematika Ditinjau Dari Kepercayaan Diri Dan Keaktifan Siswa Di Kelas. Jurnal Formatif. 6(1), 50-61.

Besten, Kris Den. (2010). Shine: Lima Prinsip utuk Membuat Usaha dan Karier Anda Melejit. Jakarta: PT Gunung Mulia.

Cahya, Harry. (2008). Quantum Asset: Mengembangkan Trilogi Asset Mencapai Hidup yang Berkualitas. Yogyakarta: Kanisius.

Harianto, Aries. (2008). Konsistensi Mediasi Hubungan Indrustrial dalam Perspektif Asas-asas Mediasi. Majalah Ilmiah. 3(2), 89-108.

Kadir. (2011). Implementasi Pendekatan Pembelajaran Problem Posing dan Pengaruhnya Terhadap Hasil Belajar Matematika. Jurnal Pendidikan dan Kebudayaan. 17(2), 203-214.

Leonard. (2015). Kajian Peran Konsistensi Diri Terhadap Prestasi Belajar Matematika. Jurnal Formatif. 3(2), 97-104.

Nashori, Fuad. (2011). Agar Anak Anda Berprestasi. Yogyakarta: Pustaka Zeedny.

Nugraha, Muhamad Lutfi. (2018). Pengaruh Persistensi Diri Terhadap Prestasi Belajar Matematika Siswa Di Smp Al-Qalam. Research and Development Journal Of Education. 5(1), 61-72.

Robbins, Stephen.P, dkk. (2010). Manajemen. Jakarta: Erlangga.

Somantrie, Hermana. (2009). Peningkatan Mutu pendidikan di Indonesia. Jurnal Pendidikan dan Kebudayaan. Vol. 15 Edisi Khusus I, 1-19.

Wahidmurni, dkk. (2010). Evaluasi Pembelajaran Kompetensi dan Praktik. Yogyakarta : Nuha Litera.

Z.M, Tatan dan Teti. (2011). Pengaruh Penggunaan Media Belajar dan Minat Belajar Terhadap Hasil Belajar Matematika (Eksperiman Pada Siswa Kelas XI IPA SMA Negeri 8 Kota Tangerang Selatan Tahun Pelajaran 2010/2011). Jurnal Formatif. 1(1), 70-81. 